\title{
The Academy, the Market and the Art Museums in the Repositioning of Australian Aboriginal Art
}

\section{David Dolan}

Volume 28, 2001-2003

Art History Inside and Outside the University

L’histoire de l'art à l'université et hors de l'université

URI : https://id.erudit.org/iderudit/1069783ar

DOI : https://doi.org/10.7202/1069783ar

\section{Aller au sommaire du numéro}

\section{Éditeur(s)}

UAAC-AAUC (University Art Association of Canada | Association d'art des universités du Canada)

\section{ISSN}

0315-9906 (imprimé)

1918-4778 (numérique)

\section{Découvrir la revue}

\section{Citer cet article}

Dolan, D. (2001). The Academy, the Market and the Art Museums in the Repositioning of Australian Aboriginal Art. RACAR : Revue d'art canadienne / Canadian Art Review, 28, 56-65. https://doi.org/10.7202/1069783ar

\section{Résumé de l'article}

La deuxième moitié du vingtième siècle a vu un changement marqué dans la manière de présenter, de collectionner et de comprendre l'art des peuples indigènes d'Australie. Les approches antérieures spécialisées (ethnographique et anthropologique) des artefacts aborigènes ont été remplacées par la reconnaissance générale que l'art indigène (qui offre des formes nouvelles souvent proches de l'art contemporain) n'est pas seulement un élément important et unique de l'art de l'Australie moderne, mais en constitue évidement l'aspect le plus intéressant pour le reste du monde.

On sait que les attitudes et les pratiques institutionnelles se sont transformées au cours des années 1970 et 1980. Dans le contexte d'un lent abandon d'une histoire lourde de politiques culturelles racistes, ces décennies constituaient un intervalle entre les premières réformes des années 1960, au moment où les aborigènes australiens eurent accès - tardivement - à la pleine citoyenneté, et les années 1990 alors que la « Réconciliation » entre les peuples indigènes et les descendants des colons devint un enjeu politique de premier plan. Au début de XXIe siècle, les productions des artistes aborigènes obtiennent les plus hautes cotes du marché de l'art, bien supérieures à ce que pouvait obtenir les autres artistes vivants.

Cet article s'interroge sur le rôle de la recherche et de l'enseignement universitaires dans la réévaluation de l'art aborigène de la culture australienne contemporaine. Nous croyons que l'histoire de l'art et les cours théoriques universitaires, le milieu du marché de l'art ainsi que les principaux musées d'art publics ont tous eu un rôle à jouer dans la transformation du statut de l'art aborigène, mais que l'université s'est contentée de suivre le mouvement avec les autres instances, plutôt que d'en montrer la voie.
Tous droits réservés (C) UAAC-AAUC (University Art Association of Canada | Association d'art des universités du Canada), 2004
Ce document est protégé par la loi sur le droit d'auteur. L'utilisation des services d'Érudit (y compris la reproduction) est assujettie à sa politique d'utilisation que vous pouvez consulter en ligne.

https://apropos.erudit.org/fr/usagers/politique-dutilisation/ 


\title{
The Academy, the Market and the Art Museums in the Repositioning of Australian Aboriginal Art
}

\author{
David Dolan, Curtin University, Western Australia
}

\section{Résumé}

La deuxième moitié du vingtième siècle $a$ vu un changement marqué dans la manière de présenter, de collectionner et de comprendre l'art des peuples indigènes d'Australie. Les approches antérieures spécialisées (ethnographique et anthropologique) des artefacts aborigènes ont été remplacées par la reconnaissance générale que l'art indigène (qui offre des formes nouvelles souvent proches de l'art contemporain) n'est pas seulement un élément important et unique de l'art de l'Australie moderne, mais en constitue évidement l'aspect le plus intéressant pour le reste du monde.

On sait que les attitudes et les pratiques institutionnelles se sont transformées au cours des années 1970 et 1980. Dans le contexte d'un lent abandon d'une histoire lourde de politiques culturelles racistes, ces décennies constituaient un intervalle entre les premières réformes des années 1960, au moment où les aborigènes australiens eurent accès - tardivement - à la pleine citoyenneté, et les années 1990 alors que la « Réconciliation » entre les peuples indigènes et les descendants des colons devint un enjeu politique de premier plan. Au début de $X X l$ le siècle, les productions des artistes aborigènes obtiennent les plus hautes cotes du marché de l'art, bien supérieures à ce que pouvait obtenir les autres artistes vivants.

Cet article s'interroge sur le rôle de la recherche et de l'enseignement universitaires dans la réévaluation de l'art aborigène de la culture australienne contemporaine. Nous croyons que l'histoire de l'art et les cours théoriques universitaires, le milieu du marché de l'art ainsi que les principaux musées d'art publics ont tous eu un rôle à jouer dans la transformation du statut de l'art aborigène, mais que l'université s'est contentée de suivre le mouvement avec les autres instances, plutôt que d'en montrer la voie.
The Context of Change

$\mathrm{D}$ uring the second half of the twentieth century, there was a marked shift in the way the art of the Australian indigenous people (Aborigines) was presented, collected and understood in Australia and indeed in the rest of the world. This shift occurred in the context of contentious and changing social and political attitudes towards ethnicity and particularly the status of indigenous people.

Obviously there was a reciprocal influence. Changes in the ways Aboriginal art was presented, collected and understood both encouraged and reflected various social and attitudinal changes. The full story of how these changes came about would easily fill a substantial book and is not being attempted here. In keeping with the theme of art inside and outside the academy, the question being asked here is whether the academy was leading these changes, or was it bringing up the rear? To answer this, we must identify in outline the different roles and timing of three main contributors to understanding and valuing of art. What role, and when, was played by art dealers, major public art museums, and university Art History and theory courses in the change in the status of Aboriginal art? In which sector was change first apparent, who led, and who followed?

Australian political discourse refers inclusively to Aborigines and Torres Strait Islanders, as reflected in the name of the peak indigenous organization, the Aboriginal and Torres Strait Islander Commission (ATSIC). This nomenclature reflects the different (Pacific and Melanesian) origins of the people of the Torres Strait Islands and nearby north-eastern Australian coast; however, this study is limited to the historically recent art of the indigenous peoples who have occupied the Australian mainland for about 50,000 years. For the benefit of international readers, it must be explained that there is not one single culturally homogenous Australian Aboriginal nation, but rather many distinct tribal or skin, clan and language groups, and many urban and regional communities with strong ties to their land. They have different languages, mythologies, cultural practices, legal systems, and contrasting local histories of interaction or coexistence with colonial invaders and settlers. They also have diverse traditions and styles in art, utilizing a wide range of traditional natural materials depending on local availability, and latterly working in modern media such as acrylic paint. The illustrations to this article representing baskets, scorched (pyrography) or painted carved wood, paintings and prints have been chosen to indicate something of the range of media and forms in which contemporary Aboriginal artists express their creativity (fig. 1).

It is beyond our scope here to look closely or directly at developments in the mode and pace of production of Aboriginal art. In recent decades, many but not all Aboriginal communities have ventured into the production of art for sale, and for some it is now a mainstay of their group's economy. This art, which also has an important political role in asserting and promoting cultural identity, includes work in traditional media and styles, and in modern and introduced materials and modes. There has been a number of studies of recent regional Aboriginal art production, but not all these histories have yet been documented. ${ }^{1}$ Inevitably, the production of the art has stimulated, and been stimulated by, academic, market and institutional interests.

It is also far beyond our scope here to give a full account of the complex history of race relations in Australia, and indeed there is no definitive history, although there is much ongoing 
Figure I. Mary Milngurr, Basket, circa 1994. Pandanus bush string and natural dyes, $31 \times 22 \times 29 \mathrm{~cm}$. Central Arnhem Land, Australia. Private collection (Photo: D. Dolan).

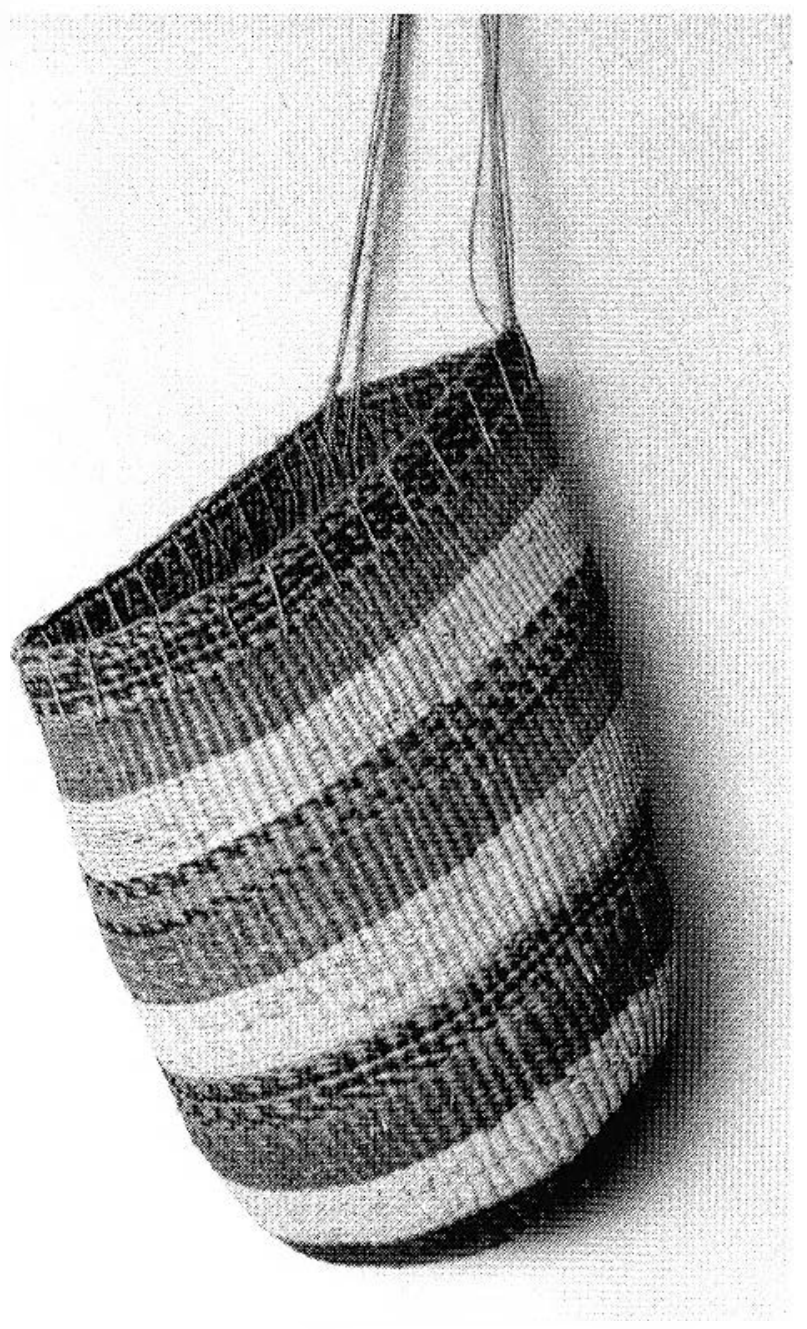

study and disputation. But some introductory overview is necessary. It is undeniable that, in the nineteenth and early twentieth centuries, the majority "white" colonial settler population ignored or displaced and repressed the indigenous people whom ignorant whites then commonly but wrongly regarded as nomadic primitives and savages. The vast majority of non-indigenous Australians were smugly unaware of the antiquity, complexity and richness of Aboriginal cultures. This was consistent with the long-standing though subsequently abandoned legal fiction of "terra nullius" which held that the Australian landmass was unoccupied before British colonization in 1788 .

In the 1930s, a few non-indigenous visual artists and poets took an interest in Aboriginal art, often appropriating stories and imagery. ${ }^{2}$ Commencing with a successful first exhibition in 1938, one central Australian Aboriginal artist, Albert Namatjira (1902-59), achieved lasting national popular recognition for his watercolour landscapes which skilfully utilized European techniques of representation but were informed by indigenous knowledge and understanding of the land. The recognition Namatjira and his immediate circle achieved was not extended to other Aboriginal artists at that time.

It was not until the second half of the twentieth century that lingering social Darwinist notions of a "dying race" and government policies of assimilation gave way to a belated general acknowledgment of Aboriginal cultural values and identity. In Australia's slow turn away from institutionalized racism, the mid-1960s saw overwhelming voter support for referenda to amend the Constitution to fully recognize Aborigines as citizens for the first time since federation of the nation in 1901, and belatedly to empower the federal government to make laws for their benefit. It was not until 1992 that Aboriginal land rights were legislated, following the landmark High Court "Mabo" case (after its initiator, Eddie Mabo) which established the existence of Native Title.

Official policies since the 1970s have been based largely on the principle of "multiculturalism" which celebrates diversity within unity and promotes respectful recognition of both indigenous and recent immigrant traditions. Earlier policies of integration and assimilation, which had sought eventually to dissolve people of indigenous ethnicity invisibly into the general population, were replaced by a recognition that indigenous culture should remain and be recognized as distinctive while being appreciated as a vital component of a pluralistic society.

In this context, earlier specialized ethnographical and anthropological interest in Aboriginal artefacts was replaced by growing awareness that Aboriginal art (which was taking new and often vividly contemporary forms) was not only an important and unique element of the art of modern Australia, but was clearly the most interesting aspect of Australian art in the eyes of the rest of the world.

During the nineteenth and early twentieth centuries, Aboriginal artefacts had been collected and displayed by scientific and general museums which also collected natural history material, but they were rarely if ever seen in art museums (generally described, following British usage, as art galleries). Public collections and touring exhibitions of Australian art were confined to art in the European, and very occasionally Asian, tradition (with perhaps a token representation of Namatjira or his school). Even the best standard published histories of Australian art, such as Bernard Smith's Australian Painting 1788-1960, omitted Aboriginal art (which was still almost solely the province of anthropological books), ${ }^{3}$ and the market was similarly differentiated. The trade in Aboriginal artefacts (real and imitation) was largely confined to low-priced tourist souvenirs.

By 2000-2001, the turn of the twentieth into the twentyfirst century, this had changed. No major collection or comprehensive survey of recent Australian art would or plausibly could omit indigenous art. New histories of Australian art, written by 
curators led by Andrew Sayers, ${ }^{4}$ illustrated and discussed the work of indigenous artists, including some rediscovered from the colonial era, alongside work in the European tradition. Leading dealers' galleries included indigenous artists in their stables, and many specialized in their work, some exclusively, commanding high prices. Aboriginal-controlled art enterprises created public murals, fashionable fabrics, and designs for the paintwork of aircraft of the national airline Qantas.

Predictably, some aspects of this explosion of production have been controversial, and there have been claims of appropriation and bitter arguments about authenticity. Several recent books give good overviews of the changing and increasing interest in Aboriginal art in the late twentieth century with particular reference to the collecting and display policies of the major art museums. ${ }^{5}$ The ambitious Oxford Companion to Aboriginal Art and Culture (eds S. Kleinert and M. Neale) embodies the high level of scholarly interest at the end of the twentieth century. Roger Benjamin, a contributor to that volume, suggests that major changes in the perception of Aboriginal art occurred in the 1980s, marked by greater volume of production and commercial exhibitions, and more interest from universities and museums, followed slightly later by international tours by artists and exhibitions. ${ }^{6}$

The present study aims to disentangle these forces chronologically, to discover exactly when and how they came into play, and also offers the first investigation of how the changes were reflected or initiated in the key journal of Australian art. It attempts for the first time to identify, comparatively analyse and differentiate the precise timing as well as the nature of the participation of the academy, the market and the major public collecting institutions in the dramatic reversal of attitude and vast increase in the visibility of Aboriginal art.

Inside the Academy

At the middle of the twentieth century, there was little interest in Art History in Australian institutions of higher education. Some very elementary Art History was taught in the practiceoriented art schools and in teachers' colleges, but demand was minimal as Art History was not part of the secondary school curriculum. Australia's first university department of Art History (called Fine Arts), established at Melbourne in 1946, remained the only one in the country for almost twenty years. The long-serving founding professor, (later Sir) Joseph Bourke, was appointed from England, and throughout his time the focus of the programme was solidly European. This was consistent with other arts disciplines: Australian material was then rarely included in university Literature or History courses. Based on the enthusiasm of one or two individuals, some universities (e.g. Western Australia and New England) built or inherited collections of Australian art, but these were usually scattered around the campus in offices or common rooms and until late in the century generally lacked dedicated exhibition space or curatorial staff.

The Flinders University of South Australia took in its first students in 1966, and Fine Arts was among the subjects although it was initially with a teaching staff of just one: former Queensland Art Gallery deputy director Robert Smith. Flinders's first professorial-level appointee, sculptor and aesthetician Donald Brook, did not arrive until the early 1970s. The University of Sydney first enrolled Fine Arts undergraduates in 1968, having appointed the Courtauld-educated Australian art specialist Bernard Smith as its foundation professor. The late 1960s and 1970s saw a proliferation of university Art History departments, with the new LaTrobe and longer-established Monash (both in Victoria), Queensland, and Western Australia also entering the field.

In the 1970s many of the art school and art teachers' courses based in restructured Colleges of Advanced Education (CAEs) were upgraded from certificate or diploma to Bachelor degree status, with some introducing Master's programmes, necessitating development or strengthening of their teaching in Art History and Theory to meet accreditation requirements. Virtually all these new university and college Art History programmes included Australian art units in their curricula, but many were almost entirely restricted to the local colonial and modern Australian branch of the European-US "international" tradition. Ph.D. theses on any aspect of Australian art were then extremely rare.

In older universities, serious consideration of Aboriginal art remained for some time confined to departments of Anthropology and Ethnography, some of which built collections of Aboriginal cultural material such as the Berndt Collection gifted to the University of Western Australia (UWA) which became more accessible when opened in museum format in 1976.

At UWA the Fine Arts area was operationally linked to Anthropology in the 1980s, then to Architecture in the 1990s. The frequent restructuring which is a feature of Australian university administration can reflect changes in alignment of academic disciplines but is not a reliable guide, as the real motives for changes were often other factors such as critical mass or balance of student numbers, or even the personal interests or relationships of influential staff members.

As time passed, the collecting, collection management, display and conservation of Aboriginal art was included in a widening range of courses on archaeology, museology and materials conservation, and of course Aboriginal cultural studies. This reflects not only increasing awareness and interest, but also the efforts of various universities to identify and claim areas of teaching and research during a period of steadily increasing 
competition between education providers, which could form the basis of an expanded study.

For the purpose of this more narrowly focused analysis, we researched the introduction of Aboriginal art into the offerings of Australian university departments of Art History, Fine Arts, or Visual Arts as they have variously been designated. An inclusive account of the full histories of all Australian higher education programmes in Art History would far exceed the size of this article, but the nation-wide pattern of developments can be followed through a selection of concise case studies.

A general shift in nomenclature, reflecting changes in course content, must be noted. The pioneering departments adopted the term "Fine Arts", which is of classical derivation and implies privileging the European tradition. The Sydney department was also constituted as the Power Institute of Fine Arts, echoing the style of the Courtauld and other European institutes. Although the University of Sydney already owned many works of Australian art, the bequest of Dr John W. Power also endowed a new collection specifically limited to non-Australian art (subsequently incorporated into the off-campus Museum of Contemporary Art which has a wider charter).

From the 1970s, as French-derived cultural theory became increasingly influential in Australia and elsewhere, the name "Fine Arts" was used less. New and restructured departments more often called themselves Visual Arts and/or Art Theory. Studies in Visual Arts and/or Art Theory can be expected to find examples for study in a wider range of artistic traditions and forms than were used in Fine Arts departments which looked, at least initially, to European models.

Some of the new programmes established in the 1970s and 1980s included some reference to Aboriginal art from their beginnings, such as at the Australian National University (in Canberra) where Art History dates from 1977. In 2002 the ANU department appointed a senior specialist in Aboriginal art to further develop this emphasis.

At Prahran College (in Melbourne) department head Noel Hutchinson rewrote the Art History units in 1981-82 as part of degree accreditation, and Aboriginal art was specifically included from then. Ten years later the Prahran College of Advanced Education art school merged with the Victorian College of the Arts (VCA) whose existing programmes heavily emphasized European and US contemporary art. Some VCA staff resisted the inclusion of Aboriginal art in the courses of the merged school, but "the student body lobbied strongly for the adoption of Prahran's programme mainly on the grounds that they wanted Australian indigenous and Asian art specifically to be taught." 7

Although coverage of Aboriginal art was further increased following a review of courses in 1996, there subsequently appears to have been a step back at VCA with staff numbers and teaching in all Art History/Theory areas including Aboriginal art, reduced by about half in 2001-02 as part of overall funding cuts which also caused the discontinuation of Asian art studies.

In the late 1960s when the present writer was enrolled in the new Flinders University BA Honours Fine Arts programme, it did not incorporate Aboriginal art. But in the late 1970s, Flinders became the first university in the country to incorporate indigenous art into a pre-existing Fine/Visual Arts course. ${ }^{8}$ This was a time of change and contestation at Flinders as emphasis shifted from history to theory. At the same time, Flinders' teaching-oriented art museum added Aboriginal art to its collecting policy. Unfortunately, personal and pedagogical differences between staff hastened the demise of the Fine/Visual Arts programme which no longer exists; but Flinders continues Indigenous Studies through Archaeology, Anthropology and Cultural Studies.

In some institutions, many years passed after the establishment of Art History programmes, before Aboriginal art was included in them. In 1992, Melbourne University introduced a Fine Arts unit entitled "Aboriginal Art and Culture", later retitled "Perspectives on Contemporary Aboriginal Art". In the 1990s, Melbourne University also established a Centre for Aboriginal Culture within the Faculty of Arts, and the centre collaborates in the teaching of Fine Arts.

Several former and current educators contacted during this research commented on the difficulty of finding staff capable of teaching courses on Aboriginal art at university level. It must be recognized that concentration on the European tradition is not necessarily indicative of racist attitudes, or even a lack of interest in indigenous art, on the part of individual university teachers. Many, the present writer included, have respectfully declined to lecture about something they understand insufficiently. This is consistent with the wishes of the indigenous community, who naturally wish to retain control over the interpretation of their own cultural tradition. However, when Art History and Theory departments have expanded beyond a mere handful of staff, but still no one with indigenous cultural expertise has been appointed, this may be an indication that Aboriginal culture is undervalued at the institutional level.

The public museum sector, and to a lesser extent the academy, also experience a problem which barely arises for the art trade: how to present or position Aboriginal art for a public who do not belong to or indeed understand much about indigenous culture. By the late 1980s, it was noticeable that senior business executives were constantly appearing in newspaper photographs or television interviews posed in offices or boardrooms adorned with contemporary Aboriginal art. Big, bold, colourful, abstract-looking but distinctively Australian, these paintings had become the politically correct backdrop of choice. Art dealers selling Aboriginal artworks to corporate or individual clients do 


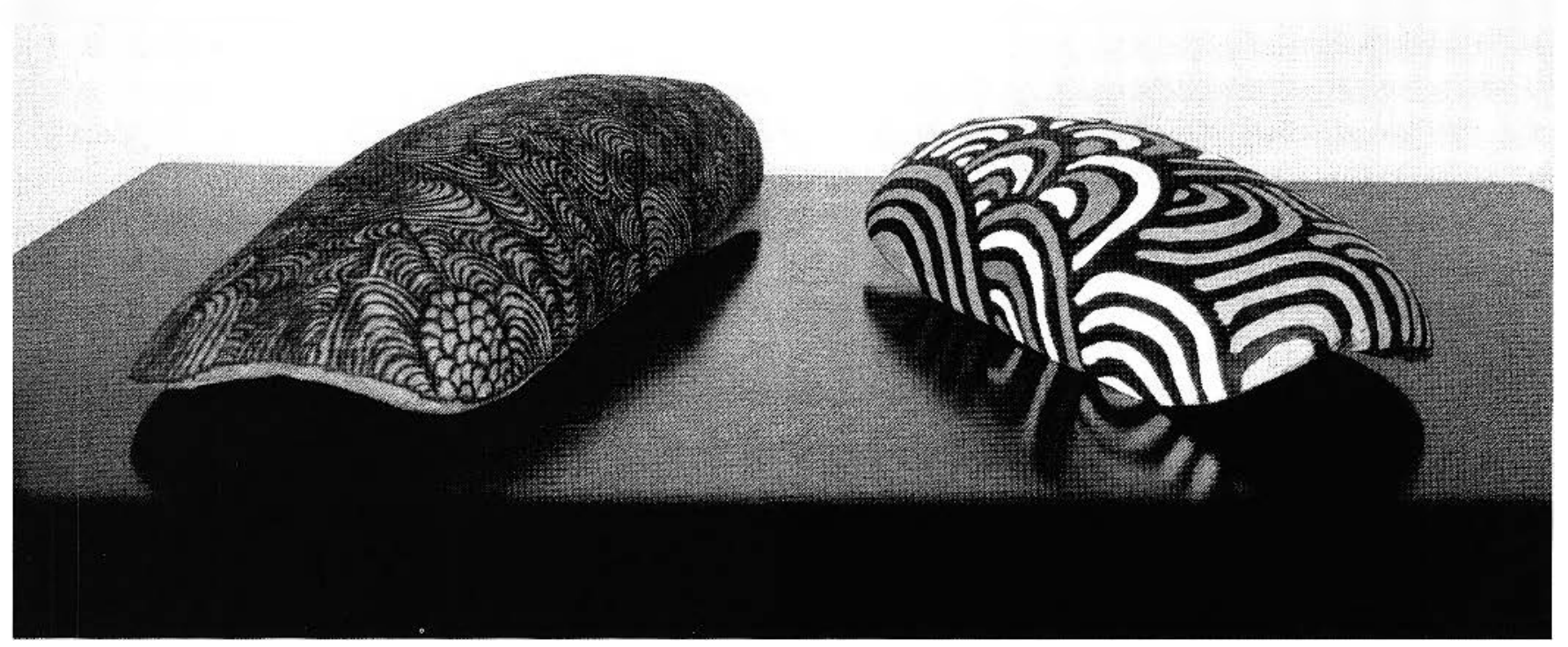

not have to worry about how the buyer (mis-)understands their purchase; but public art museums and universities quite properly assume a higher level of responsibility for the ideas they impart to their visitors and students respectively.

This dilemma has been extensively canvassed, without general resolution, over the last three decades at least, and was well summarized in 1989 by Charles Green who regretted "the tendency to promote contemporary Aboriginal art as a type of international abstract formalism..." acknowledging:

\footnotetext{
The obvious crudity of this view has always militated against the integration of Aboriginal art into the permanent hanging of galleries of white Australian art ... On the other hand, the presentation of Aboriginal art within art galleries as ethnographic objects ... tends to promote a simplified anthropological conception of the works, which are, in fact, produced now in order to circulate as artworks. ${ }^{9}$ (fig. 2)
}

Another measure of the interests and values of the academy is the awarding of honorary degrees. During the latter part of the twentieth century, Australian universities conferred honorary doctorates on a select few senior artists, but this research did not identify any such kudos for Aboriginal artists until the very end of this time-frame. David Malangi received an honorary doctorate from the Australian National University (Canberra) in 1998, and Mary MacLean from Curtin University in 2001. (It must be acknowledged that with about forty universities in Australia, there may have been some other conferrals we missed.) The University of Western Australia was intending to confer an honorary doctorate on Rover Thomas in 1997-98, but sadly his death intervened. ${ }^{10}$

To summarize the situation in the academy, it can be said that after a few initial moves in the very late 1970s, Aboriginal art was increasingly included in curricula in the 1980 s, but it was not until the 1990s that this became consistent across the various institutions which offered Art History and Theory programmes.

\section{Outside the Academy: Major Public Art Museums}

By the time that Aboriginal art had become generally acknowledged by the academy as a core component of Australian art, the same acceptance was the norm in the major public artcollecting institutions. When did the shift occur, away from the practice and policy of the first two-thirds of the twentieth century when, as we have seen, Aboriginal art had had almost zero visibility in these places?

Daniel Thomas, Australia's most experienced curator and gallery director, has claimed priority for his former Art Gallery of New South Wales (Sydney) colleague Tony Tuckson, who 


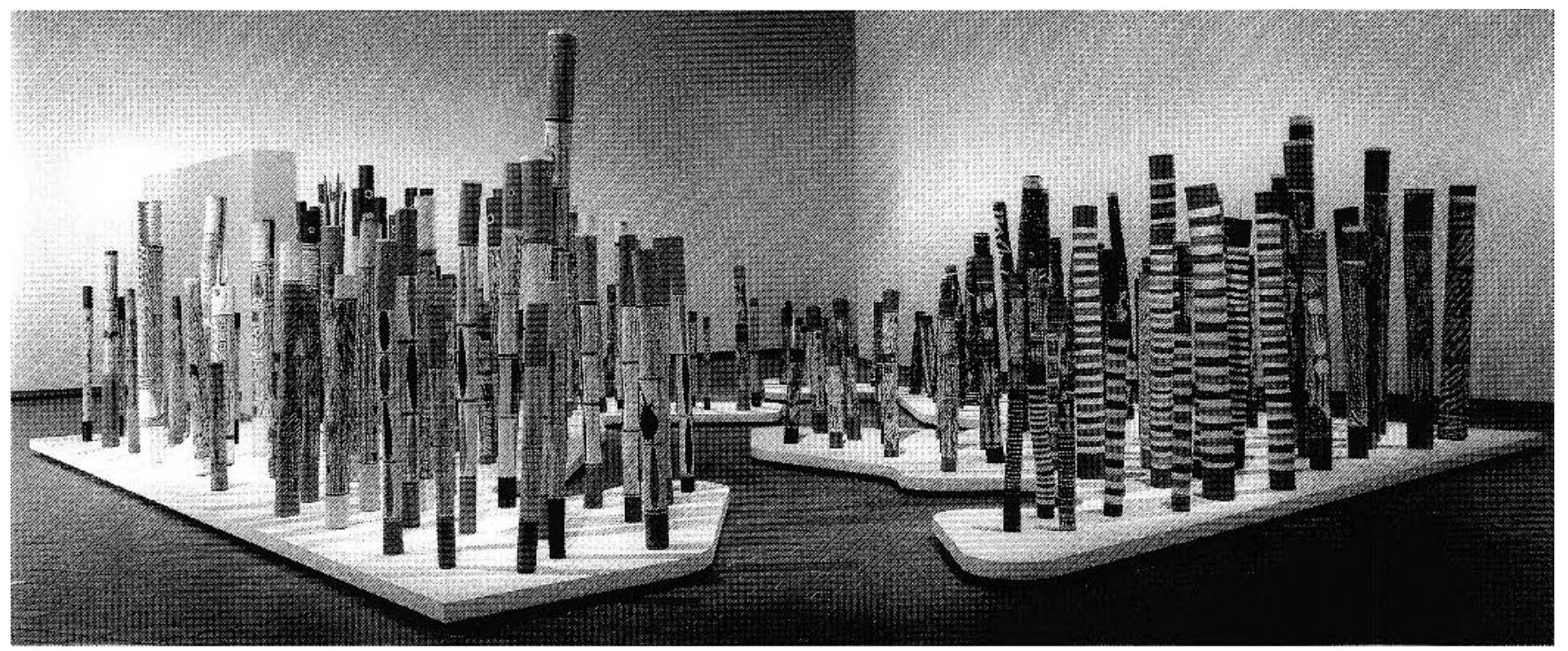

organized a touring exhibition of bark paintings in 1960, after having instigated more prominent display of his gallery's indigenous collection in the late 1950s. ${ }^{11}$ This remained the exception to the rule for many years. In Adelaide, David Thomas (no relation to Daniel) became director of the Art Gallery of South Australia in 1976 and soon announced a change in policy and priorities to acquire contemporary Aboriginal art actively. ${ }^{12}$

The creation or reconfiguration of state or federal art galleries provides a telling indicator of shifting policies and official attitudes. When the new National Gallery of Australia opened in Canberra, and the Queensland Art Gallery moved into an impressive new building, both in 1982, they included indigenous art in their opening exhibitions. The Australian National Gallery collected Aboriginal art from its inception, although it was not until after a change of directorship in 1987 that Queensland prioritized collecting Aboriginal art.

In contrast, back in 1968 when the National Gallery of Victoria (which had acquired Aboriginal art works, albeit in small numbers, from the 1940s) had opened its grand new premises in Melbourne, indigenous art was tucked away in an obscure location and remained thus for many years. The NGV did not linger permanently behind the other institutions, however. It appointed its first specialist Aboriginal art curator in 1981, and formalized its collecting of contemporary Aboriginal art with a dedicated budget allocation in 1984 at the same time as opening an Oceanic Gallery for loan exhibitions of Aboriginal art. ${ }^{13}$ Also in 1984 the Northern Territory Museum, which collected both traditional and contemporary work, instigated the National Aboriginal Art Award which was to experience its share in controversies over such issues as joint authorship in the 1990s.
Some major art events have been seen as milestones in the change of attitudes. According to Daniel Thomas, the initial move that lead to the re-evaluation of the value and place of Aboriginal art could be attributed to "the inclusion of bark painting from Ramingining, Arnhem Land in the 1979 Biennale of Sydney". ${ }^{14}$ This exhibition included the works of David Malangi and George Milpurru.

The 1988 bicentenary of British settlement in Australia focused public and political attention on history and heritage, with extensive and intense celebrations, but had only a muted, slow and indirect impact on the academy despite several official enquiries and reports into educational curricula. In contrast, virtually all public museums including art galleries mounted heavily promoted special retrospective exhibitions, with an accompanying flood of soul-searching reviews and commentary in the popular and specialist media. The patriotic and nationalistic official commemorations of the bicentennial were justly criticized at the time and subsequently, particularly for failing to come to terms with the fraught meaning of 1788 for indigenous people. Governments failed to take the opportunity for a definitive Aboriginal treaty or significant reconciliation projects.

Nevertheless, reviewing the exhibition catalogues and art journals of 1988, it is clear that indigenous art was widely included and emphasized. Highly significant was The Aboriginal Memorial (a commissioned installation of 200 hollow-log bone coffins, 1987-88, ochres on wood) by various Ramingining artists from Central Arnhem Land, at the Australian National Gallery (fig. 3). Art museum policy was ahead of cultural policy in many other sectors of government. 
Figure 4. Trevor Nickolls, Bird. c 1985. Screenprint, $58 \times 40 \mathrm{~cm}$. (image). Private collection (Photo: D. Dolan).

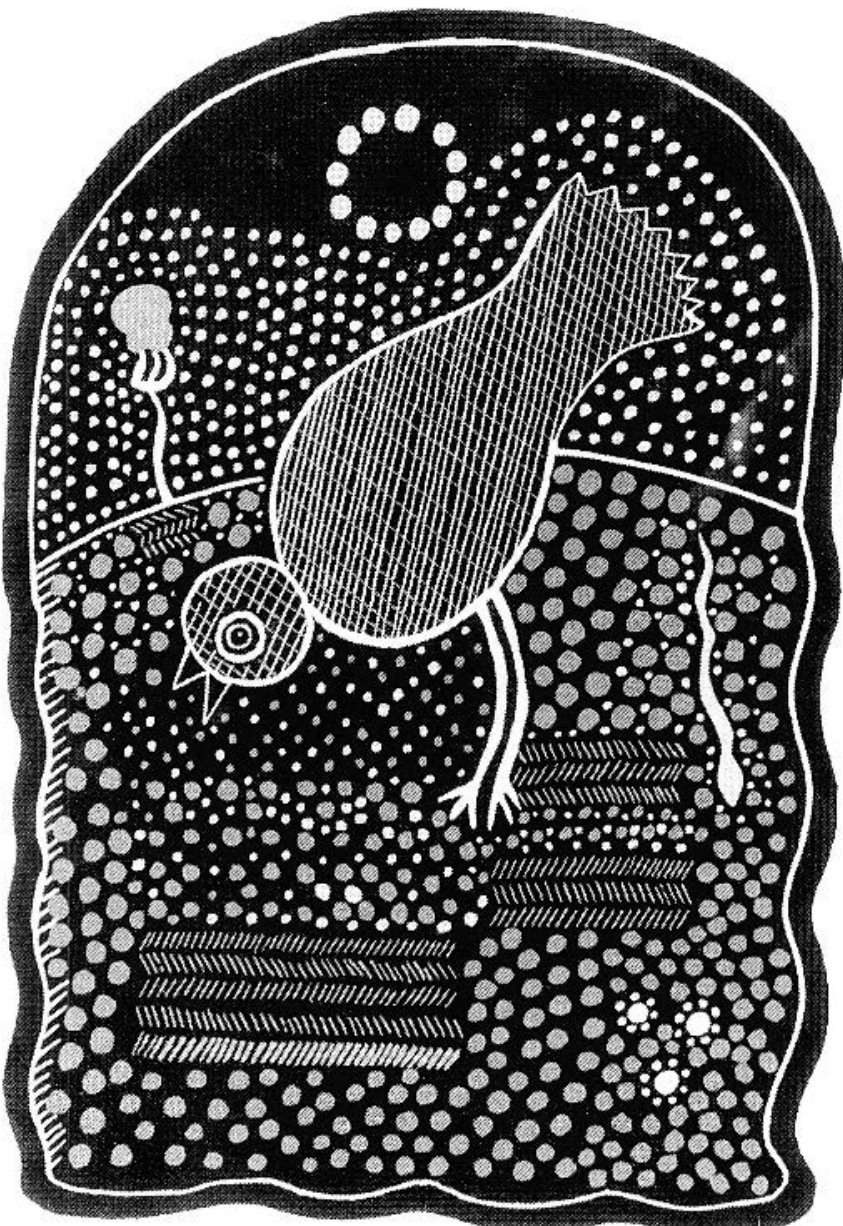

There were rwo stages in the process of the re-evaluation and inclusion of indigenous art by public art museums. The first step, outlined in the preceding paragraphs and firmly established by the mid-1980s, consisted of giving greater emphasis to collecting and displaying indigenous art and acknowledging its standing as Art. Implicit in this stage was the understanding and implication that indigenous art was a self-contained cultural category or tradition (fig. 4). ${ }^{15}$ During the 1990 s all major public art museums staged significant exhibitions of Aboriginal art. The second step also occurred in the early 1990s when it suddenly became normal practice for indigenous art to be included alongside non-indigenous art in survey exhibitions, for example "Balance 1990" at the Queensland Art Gallery. ${ }^{16}$

Since the 1980s there has been a steady increase in the number and ratio of art museum staff dedicated to Aboriginal art, and in the 1990s it became common policy to recruit curators and education officers from indigenous backgrounds actively. Curatorial staff appointments are an indicator of institutional commitment to particular streams or modes of art, but cannot be interpreted simplistically. The creation of specialist Aboriginal art curatorships and departments in art museums brings in dedicated expertise, but may be perceived as reinforcing a separation of indigenous and "colonial" (Europeanderived) collections. Should such positions and departments be confined to the management of earlier (traditional) artworks and artefacts, with work by contemporary Aboriginal artists integrated into comprehensive contemporary Australian holdings?

The contested connotations of the word "integration" point to the dilemma: while social policy has rejected older notions of assimilation and integration into a dominant majority culture, there has been growing support for the inclusion of indigenous artworks into "national" exhibitions and collecting programmes. Social and political attitudes to multiculturalism and pluralism are still changing and developing, so it may be some time yet before consensus is reached on many of these issues.

Furthermore, there has long been a symbiotic relationship between art collectors, collections and museums, on the one hand, and dealers and the art market, on the other. Dealers supply and to varying degrees influence the development and shape of public collections and private collections (which may eventually, in whole or in part, become public).

Equally, curators are seen as gatekeepers, and museum exhibitions promote and validate art. Museum curators often maintain close and mutually beneficial contact with dealers; and in recent years, with increasing corporatization of the public sector, individual career moves between the trade and museum curatorships and trustee roles have become more usual. It is therefore unrealistic to insist on an absolute separation of the operations of the art market and the collecting institutions (fig. 5).

Outside the Academy: The Art Market

Throughout the period of this study, those years when the place of Aboriginal art in Australian culture was being redefined, the house journal of Australian art has been Art and Australia. (The name deliberately echoes Art in Australia, a long defunct but fondly remembered journal of the 1920s and 1930s whose title is still owned by another publisher.) Numerous other Australian art magazines, both national and localized, have come and gone; with the surviving national stayers of recent years led by the theoretically inclined Artlink, the more commercial Craft Arts, and the topical Australian Art Monthly. All were established in the 1980s, too late to record the early stages of the shifts in the positioning of Aboriginal art.

The methodology of this part of the research was a quantitative and qualitative analysis of the content of Art and Australia, which has been continuously published quarterly since 1963 , thus providing the only consistent single window onto 
Dolan / The Academy, the Market and the Art Museums in the Repositioning of Australian Aboriginal Art

Figure 5. Vera Bryant, Kungkaragkalpa, c. 1996. Acrylic on canvas, $46 \times 36 \mathrm{~cm}$. Private collection (Photo: D. Dolan).

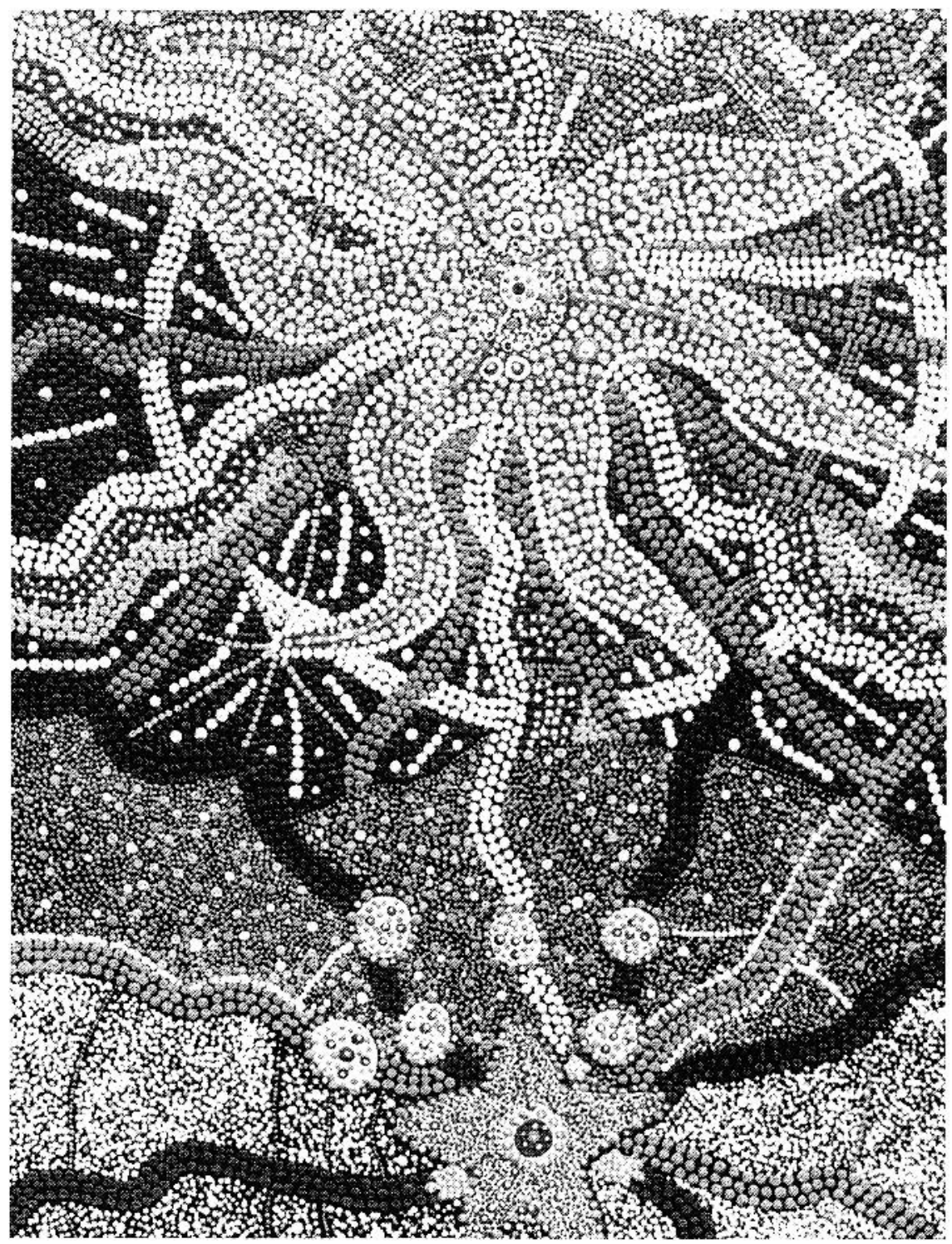

to identify the changing proportion, visibility and representation of Aboriginal art within Art and Australia over the relevant decades: the 1960s to the 1990s.

From its beginnings in the early 1960 s, Aboriginal people and art were visible if not prominent in Art and Australia. Volume 1, number 1, in May 1963 included an article, "Journey to Gallery Hill," by the senior nonindigenous artist Russell Drysdale with illustrations including photographs of petroglyphs near Port Hedland in Western Australia. The second number had no references to Aboriginal art except indirectly via appropriations by the recently deceased artist Margaret Preston.

The majority of appearances of Aboriginal art in the first years of Art and Australia are in advertisements by dealers in "tribal", "primitive" or "native" art, and lists of numerous public gallery acquisitions of "traditional" work, advertisements for books on Aboriginal culture, and reviews of books and films such as Qantas promotional shorts. These latter exemplify the fact that although seen in anthropological rather than contemporary high art terms, Aboriginal art was incorporated into a nationalistic image of Australian uniqueness as the property of all Australians. In general, in these years, Aboriginal people were present chiefly as subjects in the work of non-indigenous artists, and the merit of their art was assessed in terms of it being traditional or authentic. In a book review in 1964, Anthropology Professor R.M. Berndt wrote: the development of later twentieth-century Australian art promotion and marketing. Although accessible in language and style for a wide educated popular readership, as well as art professionals, the vast majority of its editors and writers come from the ranks of curators and academics.

Despite intermittent grant funds, Art and Australia has been chiefly and in more recent years almost exclusively financed by subscribers and advertisers. Its advertisers are mostly dealers, with some public art museums. Articles cover contemporary and historical art, including artists represented by leading dealers and in major collections, and include reviews of art books and exhibitions. For the purpose of this analysis, both advertisements and editorial text have been studied and tabulated by Curtin University researcher Andrea Carroll, in order
There are magnificent examples of contemporary Arnhem Land bark paintings and carvings (often but not always, traditionally based), new in the fullest sense of the word. What is more, these Aboriginal artists are compering with Australian-European artists. The high prices paid for their bark paintings are evidence of this. Then, in addition to the craft work produced by white Australians therc is the vast quantity of tourist productions made by Australian Aborigines: there are certainly tawdry items among them, but there are also some of high aesthetic quality. ${ }^{17}$

Not until 1973 were individual Aboriginal artists, rather than regions and communities, identified in advertisements or 
Figure 6. Paddy Fordham Wainburranga, Untitled, c.1990. Acrylic on canvas, $69 \times 78 \mathrm{~cm}$. Private collection (Photo: D. Dolan).

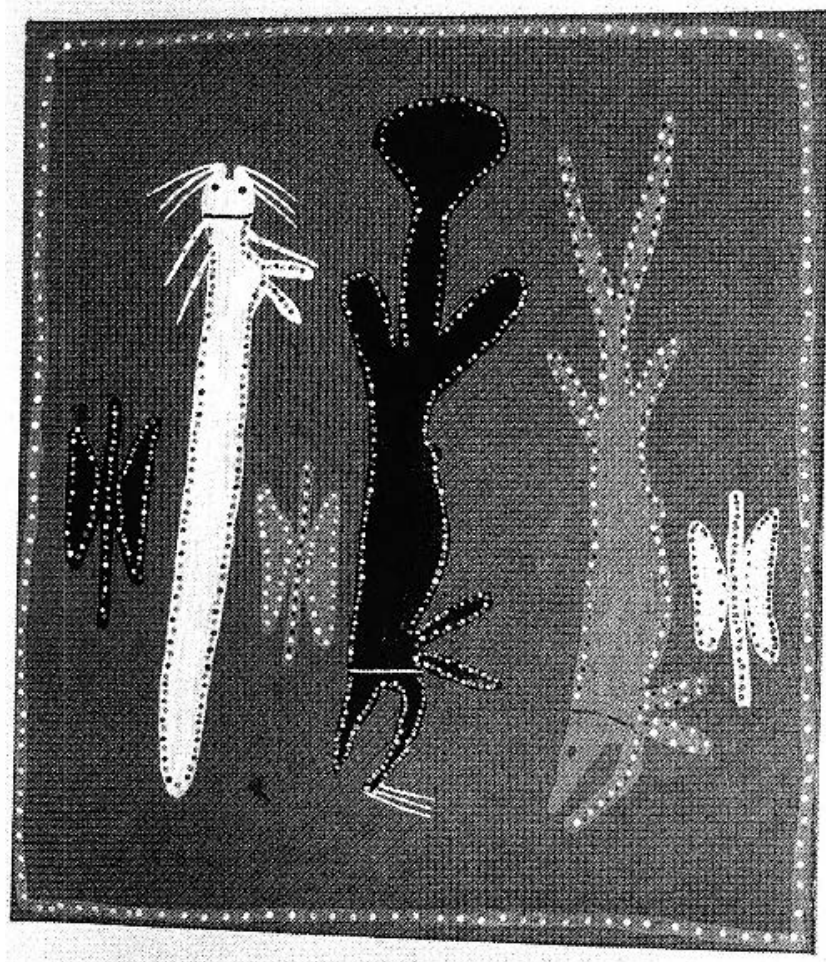

blocklines to illustrations. Then in 1976 came the Art and Australia "Special Issue on Australian Aboriginal Art" (volume 13, number 3 ), in which contemporary creative production and administration (the Aboriginal Arts Board, and copyright issues) appeared virtually for the first time alongside the traditional. In fact, this is the first issue in which the word "contemporary" is applied to Aboriginal art, and the fact that it immediately became ubiquitous in subsequent issues of Art and Australia suggests that this special issue was a watershed.

During the 1970s we find a number of advertisements and reviews for Aboriginal exhibitions in university art museums, but these almost all appear to have been of artefacts from private collections (fig. 6).

The majority of dealers advertising Aboriginal art in the 1960 s and 1970s were self-declared "tribal" specialists, but galleries which mostly showed European-tradition art were increasingly scheduling one or two indigenous art exhibitions each year but not apparently mixing indigenous and non-indigenous art in the same shows. Dozens of indigenous artworks had been used in these decades to illustrate reviews or dealers' advertisements, but it is not until 1981 (volume 19, number 2) that we see a full-page colour advertisement devoted to a single work by an Aboriginal artist. In the 1980s dealers began to refer in advertisements to "traditional and contemporary" Aboriginal art, and to market "urban" Aboriginal art. Some galleries mar- keting Aboriginal art were assisted with public funds as a matter of government policy.

None the less, the "primitive and tribal" categorization remained common in advertisements through to the 1990s. As this terminology is almost never heard in speech in Australia, it seems reasonable to speculate that its use in advertisements is a concession to the international art trade and collectors.

After three of Australia's most famous non-indigenous artists, Brett Whiteley, Sidney Nolan and Arthur Boyd, died in the last decade of the twentieth century, it emerged that senior indigenous artists were now the most highly priced living Australian artists. Ac the start of the twenty-first century, auctioneers and dealers for the leading Aboriginal artists were getting over a quarter of a million (Australian) dollars (equivalent to almost $\$ 150,000$ US) for major paintings. The only Australian works which commanded higher prices were certain rare nineteenthcentury colonial works that could attract over $A \$ 1$ million.

\section{Conclusion}

Looking back at the roles of the market, the public collecting institutions and the academy in the repositioning of Australian Aboriginal art in the late twentieth century, it appears that these three forces moved approximately together. At mid-century, all relegated indigenous art to a "primitive" anthropological category. Expanded production, use of new materials, and increased promotion in the marketplace began in the 1970s and built up to a boom in the 1990s. The art museums deserve credit for beginning the repositioning process, intermittently in the 1960s, and then vigorously in the 1970s and 1980s, reflecting and possibly sometimes leading changing social and political values.

The academy also began to revise, upgrade and update its attitudes in the 1970s, but it cannot be said to have led the changes. The 1970s was the decade of greatest prosperity and innovation in Australian higher education, with the 1980s a decade of consolidation, and the later 1990s years of contraction as the federal government reduced its commitment to public education. While the academy struggled under siege from "economic rationalism", museums mostly increased their budgets and ambitions, and the art market roared ahead along with shares, real estate and foreign investment. This case study does not permit us to position the academy as the leading agent of cultural change in Australia: indeed, that might be too much to expect in an era of late capitalism triumphant.

\section{Acknowledgments}

Andrea Carroll undertook extensive research without which this overview could not have been collated. In addition to the experts quoted and cited in the text and footnotes, we are 
grateful to the following university and art museum staff members among those who responded to our enquiries, kindly providing valuable and in some cases detailed information, and pointing us in useful directions: Professor Jaynie Anderson, Dr Roger Benjamin, Dr Edward Colless, Brenda Croft, Professor Graeme Davison, Alan Dodge, Gail Greenwood, Dr Sasha Grishin, Dr Alison Inglis, Alison Lee, Dr Nancy Underhill, Margie West.

\section{Notes}

1 Geoffrey Bardon, Pupunya Tula: Art of the Western Desert (Sydney, 1991).

2 Humphrey McQueen, The Black Swan of Trespass (Sydney, 1979).

3 Bernard Smith, Australian Painting 1788-1960 (Melbourne, 1962).

4 See especially Andrew Sayers, Australian Art (Melbourne, 2001).

5 H. Morphy, Aboriginal Art (London, 1998).

6 S. Kleinert and M. Neale, eds, Oxford Companion to Aboriginal Art and Culture (Melbourne, 2000), 454.

7 Dr Christopher Heathcote, lecturer and critic, personal communication, 28 May 2002.

8 Professor Vincent Megaw, Flinders University anthropologist, personal communication, May 2002.

9 C. Green, "Aboriginal art of the top end" [exhibition review], Art and Australia, 27, no 1 (1989), 60-61.
10 Personal communication from Christine Lewis, formerly curatorial officer at Lawrence Wilson Art Gallery, UWA, 1998.

11 Daniel Thomas, "The margins strike back", Art and Australia, 26, no 1 (1988-89), 60-71.

12 This policy development was personally communicated by David Thomas to the present author David Dolan who featured it in his regular art critic's column in the Adelaide daily newspaper The Advertiser. I have not been able to locate the date and page reference from 1976.

13 Judith Ryan, National Gallery of Victoria curator, personal communication, 13 May 2002.

14 Daniel Thomas, "The margins strike back".

15 A signal event was the selection of urban indigenous artist Trevor Nickolls (b. 1949) and the older regionally-based Rover Thomas as the Australian contribution to the 1990 Venice Biennale. The Australian edition of Time magazine devoted a cover to illustrating a detail of Nickolls's painting "Inside Looking Out", with the wording "Black Art Breaks Into a White World. Boomtime for Aboriginal Paintings" (Time Australia, 16 July 1990).

16 See Balance 1990: Views, Visions, Influences, exh. cat., Queensland Art Gallery (Brisbane, 1990). This was one of the first major contemporary survey exhibitions to present indigenous and nonindigenous art together.

17 Art and Australia, 2, no. 1 (May 1964), 63-65. 